\title{
FDI and the Subprime Crisis: An Analysis for Asian and Latin American Countries
}

\author{
Priscila G. Castro ${ }^{1}$ \& Antônio C. Campos ${ }^{2}$ \\ ${ }^{1}$ Federal Institute of Education, Science and Technology of Mato Grosso (IFMT), Cuiabá, Brazil \\ ${ }^{2}$ School of Rural Economy, Federal University of Viçosa(UFV), Viçosa, Brazil \\ Correspondence: Instituto Federal de Mato Grosso, A/C Priscila Castro, R. Zulmira Cana varro, n. 93, Centro, \\ Cuiabá MT, Brasil, 78005-000.
}

Received: September 15, 2017

Accepted: October 16, $2017 \quad$ Online Published: October 24, 2017

doi:10.5539/ibr.v10n11p206

URL: https://doi.org/10.5539/ibr.v10n11p206

\begin{abstract}
In recent decades, the inflows and stocks of foreign direct investment (FDI) have been heading increasingly towards developing countries intensifying the dynamics of international business. However, in 2008 the international financial crisis hit the world economy, decreasing FDI levels on a global scale. In this context, the purpose of this study is to evaluate the impact of the international financial crisis on FDI in Asian and Latin American countries, and to accomplish that, an analytical model was estimated by using dynamic panel procedures. Among the results, it was observed that the 2008 crisis had a negative impact on the multinational companies affecting the FDI stocks in the countries under consideration. However, the impact on the two regions differed, as the reduction in FDI stocks in Asia was greater than that in Latin American countries. In addition, the extension of the crisis, after 2008, was favorable to the growth of FDI in both regions.
\end{abstract}

Keywords: Asian countries; dynamic panel; financial crisis; foreign direct investment; Latin American countries; multinational companies

\section{Introduction}

Recently, the view that foreign direct investment (FDI) can benefit developing countries through modernizing and developing their economies has been disseminated. There is both empirical and theoretical evidence that FDI can contribute to economic growth by increasing competition among firms and improving a country's technological capacity, which, in turn, raises the levels of employment (Herman, Chisholm \& Leavell, 2004; Blomström \& Persson, 1983). The favorable relationship between FDI and national economic performance is linked to a country's capacity to absorb these capital advantages. This capacity is determined by economic and institutional factors, such as economic growth, the financial system's level of development, human capital quality, quality of infrastructure, and regulation of capital input (Dunning, 1988; Borensztein, De Gregorio \& Lee, 1998; Alfaro \& Chen, 2010).

In recent decades, the flow of FDI into developing countries has increased significantly. These countries received only $16 \%$ of the total FDI inflow in the early 1990s, with this share increasing to $34 \%$ in the middle of that decade and reaching 54\% of total inflow in 2012 (UNCTAD, 2015). However, this inflow of FDI to developing countries varies significantly between regions. Among the emerging countries, the Asian countries, especially the East and Southeast Asian countries, followed by the Latin American countries, stand out as the main investment inflow recipients. African countries and other Asian and Oceanic countries are less relevant in this context, as shown in Figure 1. 


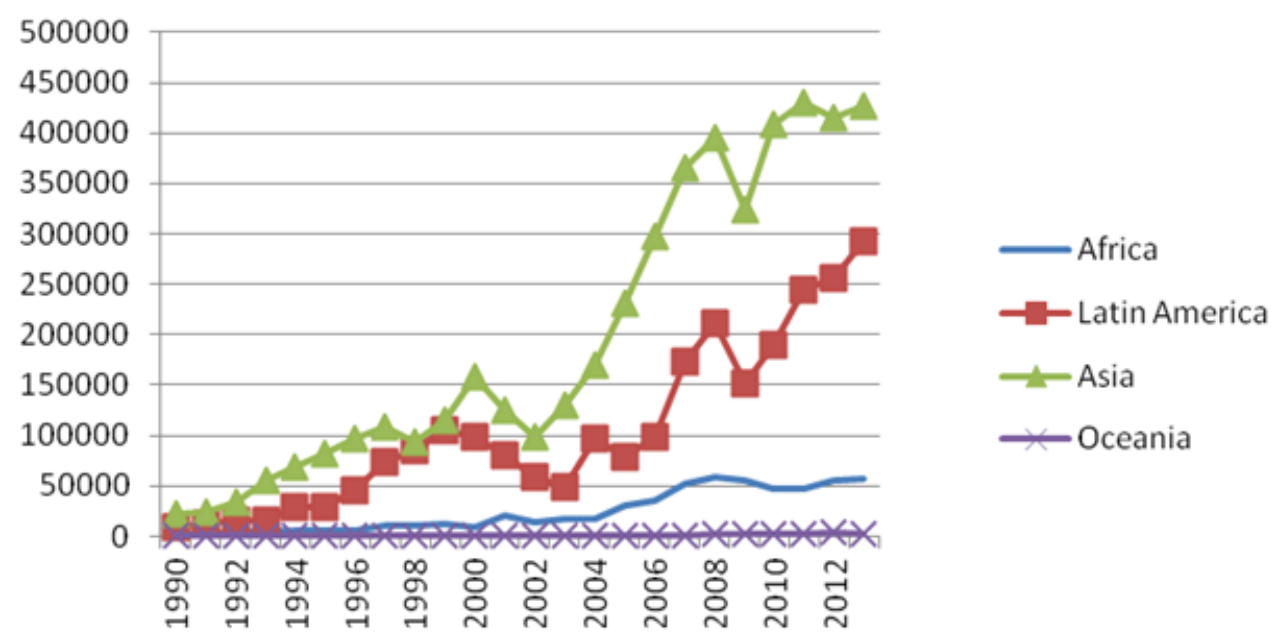

Figure 1. FDI inflows to developing countries from 1990 to 2013, US\$ millions

Source: UNCTAD, 2015.

Among the Asian emerging markets, East Asia (especially China) and Southeast Asia are the main sub-regions receiving FDI. From 2000 to 2005, these sub-regions received about 80\% of the FDI inflows into Asian developing countries, accounting for almost $85 \%$ of the investment stock (UNCTAD, 2005). A more attractive environment for FDI in these regions seems to have been created by the growth of these economies in the 1990s, including the Chinese economic expansion and dynamism, taken in association with other factors, such as cheap and high-quality labor, high levels of education in some countries (e.g., South Korea), tight integration with the global economy, and institutional reforms in favor of market functioning (Hsieh \& Hong, 2004; Barros, Chen \& Damasio, 2013).

In Latin America, participation in the total FDI inflows was only 5\% in the late 1980s, accounting for only 5\% of the investment stock worldwide. This situation has changed since the mid-1990s, with the region recording share in total FDI inflows of up to $12 \%$, reaching $7 \%$ of the world's capital stock (UNCTAD, 2005). The reasons for this increase in the attractiveness of FDI include the trade-liberalization process in the region/countries; the creation of regional trade agreements, such as NAFTA (North American Free Trade Agreement) and MERCOSUR; the privatization process; and the macroeconomic and institutional changes in key Latin American countries (Amal \& Seabra, 2007; Penfold, 2014).

There was a marked drop in FDI inflows by the end of 2008, when the world economy began to feel the effects of the global financial crisis that had started with the subprime crisis in the US market. This crisis also had negative effects on capital, production, employment, and trade across the world (Alfaro \& Chen, 2010). With regard to FDI, there was a generalized drop in stocks and flows, mainly between 2008 and 2009. During this period, the global inflow of FDI fell by $33 \%$, while stocks fell $14 \%$. In the de veloped economies, flows declined by $40 \%$ and stocks declined by $16 \%$, on average, whereas, in the developing countries, the declines were $21 \%$ and $6 \%$, respectively (UNCTAD, 2015).

Since 2010, however, several developing countries, such as China, Brazil, and India, have started to show signs of improvement in their economic performance. On the other hand, the developed countries have been facing the financial crisis, which has unfolded and caused a public deficit crisis in the European Union (EU). This is regarded as an extension of the subprime crisis. Also, since 2010, the growth of global FDI inflows has resumed in some areas, albeit at levels below those prior to the start of the crisis. In Asian emerging countries and in Latin America, FDI levels have increased above their levels at the beginning of the crisis (see Figure 1).

FDI inflows over the decades of 1990 and 2000 increased worldwide and were increasingly aimed at de veloping countries, especially East/Southeast Asia and Latin America. Nevertheless, the erupting financial crisis (subprime) seems to have stopped this expansion briefly (at the beginning of the crisis) and may have favored the subsequent attraction of FDI to the countries concerned (when considering the expansion of the crisis in the European countries).

The literature on this subject shows that most studies of the subprime financial crisis and FDI involved qualitative analysis, reporting the possible causes and effects of investment fluctuations during the period and 
drawing comparisons with past crises (Poulsen \& Hufbauer, 2011; Ramamurti, 2011; UNCTAD, 2010). Overall, these studies show that the crisis led to a decline in FDI in both de veloped and de veloping countries due to the risks and uncertainties associated with the fragility of the global economy (UNCTAD, 2010).

Few empirical studies, however, have dealt with the relationship between the recent financial crisis and FDI levels in developing countries. Ucal, Özcan, Bilgin and Mungo. (2010) demonstrated this relationship by analyzing a semi-parametric model of whether the FDI inflows were affected in the periods before and after the international financial crisis (subprime). The model results indicated that FDI inflows in the developing countries fell in the years after the crisis, i.e., after 2008, whereas they grew considerably in the years before 2008 . However, this study was limited to analyzing data until 2011, and it neither differentiated regions involving the emerging countries nor explained the reasons for fluctuations in FDI. As previously reported, the developing countries are quite heterogeneous in terms of attracting FDI.

Thus, this study aims to evaluate the impact of the international financial crisis (subprime) by considering its influence on FDI in the Asian and Latin American emerging countries during 1995-2014. This involves an issue that has been poorly addressed in the literature, as there is no defined theoretical framework and there are few empirical contributions. Furthermore, it is still important to understand the effects of the international financial crisis on FDI and the consequent effects on various aspects of the world economy. For many developing countries FDI compensates for the lack of domestic private investments, and it is associated with potential benefits for national economies (UNCTAD, 2010). In addition, the findings of this study may also be useful for comparisons with other regions and countries that attract large amounts of FDI.

Following this introduction, the article is divided into four sections. The background section discusses some effects of financial crises and their relationship with FDI, especially in the subprime crisis. The methodology section describes the analytical model, data sources, and econometric procedures. Econometric model results and discussions are presented in the fourth session. Finally, the conclusion section emphasizes the study's contributions and its implications.

\section{Background: Financial Crises and Their Relations with FDI}

Until 2008, very few financial crises had occurred in the developed economies, and absolutely none at all occurred from World War II until 1970s. In the emerging markets, the frequency of financial crises have escalated through the 1970s, 1980s and especially 1990s, due to increasing financial deregulation in their economies (Taylor, 2012). Considering financial crises against this background opens up broader concepts. According to Goldsmith (1982), financial crises are linked to a sharp, brief, and ultra-cyclic deterioration of financial indicators, such as asset prices, credit, short-term interest rates, and financial institution collapse. According to Kindleberger and Aliber (2005), crises are, in general, related to economic cycle peaks that occur during a period of economic growth, leading to a period of depression. Crises can be of either domestic or foreign origin, can start in either the private or the public sector, with different forms and intensities, and can spread swiftly across borders (Claessense \& Kose, 2013; Reinhart \& Rogoff, 2009).Despite both the complexity of financial crises and the differences between them, they tend to have similarities in terms of macroeconomic and financial consequences, as these go beyond the uncertainty they create. Often, financial crises involve significant changes in the credit volume; severe disruptions in financial intermediation, especially in foreign credit supply; impacts on the currency and the exchange rate, consequently, serious problems with the balance of payments; and need for massive go vernmental support. In addition, financial variables such as credit and asset prices tend to either fall or grow less in periods of turbulence (Claessense \& Kose, 2013). In addition, at the level of firms, studies show that financial crises are associated with sharp reductions in $R \& D$, employment, and investments in general, which leads companies to lose growth opportunities (Campello, Graham \& Harvey, 2010).

Growth prospects are increasingly harmed as financial crises evolve into economic crises (ECLAC, 2009). In this sense, investment levels tend to be affected to a large scale in times of crisis through several interrelated and mutually influenced channels: credit crush, economic growth reduction, and increased uncertainty, which leads investors to be more cautious and to postpone their investments (Minsky, 1986; Joyce \& Nabar, 2009).

FDI is a type of investment that allows an investor resident in another economy to either exert control over or significantly influence enterprise management (OECD, 2008). FDI is a result of medium- and long-term decisions and is not usually affected over the short term. The FDI response to crises and turbulence can be less significant than is the response of speculative capital, which is more volatile, and may exhibit a lag that will be perceived in periods after the crisis bursting (ECLAC, 2009; UNCTAD, 2010). Planned or future transnational investments may be affected by pessimistic crisis situations, depending on the severity, extent, and type of crisis. 
However, it is believed that investments already in progress are still implemented and finalized when a crisis erupts. In this sense, studies on the relationship of the Asian crisis (1997) and the Mexican crisis (1994) to foreign investment showed an FDI behavior that was more stable than other types of investment, such as portfolio (Athukorala, 2003; Lougani \& Razin, 2001; Lipsey, 2001; Krugman, 2000; Graham \& Wada, 2000).

However, FDI may fall in crisis situations, despite being more stable than other types of investment. Credit conditions and growth prospects, as well as the economic, political, and business environment, are factors that influence the investment decisions of transnational corporations: thus, they are FDI determinants (Dunning, 1988; Blonigen, 2005). If the crisis spreads, and these factors are affected, the probability of a decline in FDI also increases. That is, despite being a less volatile investment type, FDI can be hit by an overall financial crisis through its determinants.

When considering the crisis and post-crisis periods, it can be seen that FDI levels may even increase (Krugman, 2000; Athukorala, 2003). Due to currency depreciation, demand contractions and financial collapse can cause a decrease in the domestic asset price. This favors the so-called asset-seeking strategy of transnationals (Note 1), as there is an investment cost reduction in assets and enrichment in terms of market power. Also, as an economic recovery measure, many go vernments may adopt more liberal policies relating to foreign capital, which can open new opportunities for mergers and acquisitions (Krugman, 2000). This is the fire-sale hypothesis, developed by Krugman (2000), which is based on the financial crisis among the Asian Tigers in the late 1990s.

Thus, it is clear that FDI is seen in the literature as a more stable investment type, although it may suffer falls during crises, and as less expressive than other types of investment, such as portfolio. Also, financial crises tend to impact the FDI level by affecting its determinants, especially factors related to macroeconomic and institutional performance. Furthermore, FDI can be critical to the economic recovery of countries in post-crisis periods.

\subsection{The Subprime Crisis}

The recent international financial crisis, the greatest crisis since the 1929 Great Depression, was generated from 2007 to 2008 by the subprime crisis in the US market and soon expanded into the world economy. Generally speaking, this financial crisis originated in the USA with subprime mortgages and their subsequent default. In short, the low interest rates and good financing conditions in the 1990s made many people buy real estate and borrow what they could, with banks even lending to high-risk customers (at higher interest rates). With an increase in the US interest rates and a slowing economy, defaults had been increasing since 2001. As the fund bonds were negotiated by various financial institutions, the solvency crisis spread in the US financial system and later in the global financial system, resulting in the emergence of the crisis on the public stage in mid-2008 (Allen \& Carletti, 2009).

The crisis led to a collapse of the large commercial and investment banks (e.g. Lehman Brothers, Bear Sterns, and Merrill Lynch); a significant decline in stock prices, followed by marked loss of confidence in this market, a large increase in unemployment, and a fall in production in various countries (Mello \& Spolador, 2010). The advance of the crisis eroded the prospects for economic growth, one of the key drivers of FDI, as it limited access to internal and external financial resources and increased uncertainty, thereby increasing the risk for investors (Poulsen \& Hufbauer, 2011;ECLAC, 2009).

The extension of the subprime crisis hit the European market and led to a public deficit crisis in the EU. In general, there was a transfer of the real estate debt bubble to public debt as an emergency measure to save the European financial systems. However, this measure compromised the accounts of many countries by increasing public debt, particularly in Greece, Portugal, Spain, Italy, and Cyprus. Consequences of the European crisis included political problems in the EU framework; reduced credit in the most affected countries; high unemployment rates; recession, or low growth of gross domestic product (GDP); popular dissatisfaction; and capital and investment outflow (Mongelli, 2013).

During the crisis, the global FDI stocks fell from US\$18 trillion in 2007 to US\$15 trillion in 2008 (UNCTAD, 2015). Investment inflows fell by $16 \%$ in 2008 and inflows fell by $33 \%$ in 2009 , when the global economy contracted. This decrease was more significant in developed economies, reaching $40 \%$, on average, and $21 \%$ in the developing countries (UNCTAD, 2015). At the firm level, financial crisis imposes liquidity restrictions on transnational corporations, limits access to credit, and promotes more cautious behavior by managers, who may restrict large infrastructures and risk projects (Polsen \& Hufbauer, 2011).

In Latin America, the overall drop in FDI inflows was approximately $41 \%$ between 2008 and 2009, although this figure excludes financial centers. The investment stock in the region fell from US\$ 980 billion in 2007 to 
US\$ 930 billion in 2008, a decrease of 5\% (UNCTAD, 2015). However, in 2010, the FDI levels grew again in Latin America and the Caribbean, and the region attracted about US\$ 125 billion in FDI, 40\% more than in 2009.

In Southeast Asia, the crisis led to a drop in FDI in 2008, when the investment retreated by $42 \%$ over the previous year. In East Asia, this drop in inflows was 17\% between 2008 and 2009. The reduction in inflows also affected the stock investment level in the sub-regions in question; these decreased from US\$2.40 trillion in 2007 to $\$ 2.1$ trillion in 2008-a reduction of $12 \%$ (UNCTAD, 2015). Nevertheless, in 2010, despite these effects of the crisis, the East and Southeast Asia attracted US\$ 330 billion in FDI-34\% more than in 2009-thereby raising investment stocks to $\$ 3.1$ trillion.

The falls and recoveries in FDI flows and stocks in these regions can be seen in Figures 2 and 3.

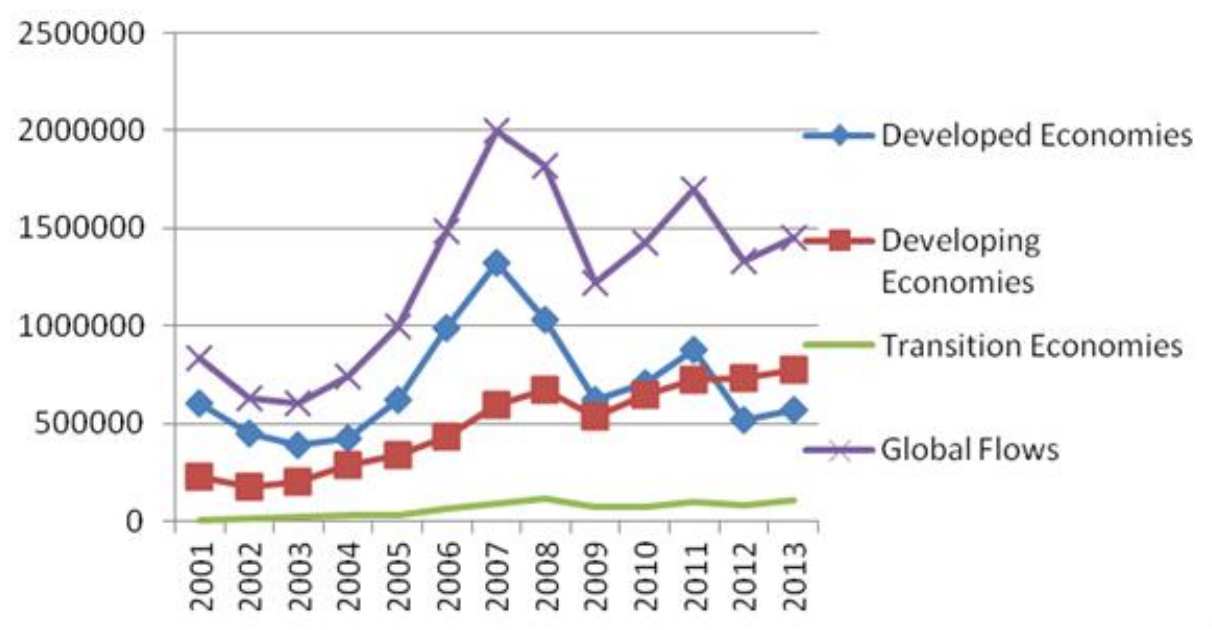

Figure 2. Global FDI inflows from 2001 to 2013, US\$ millions

Source: UNCTAD, 2015.

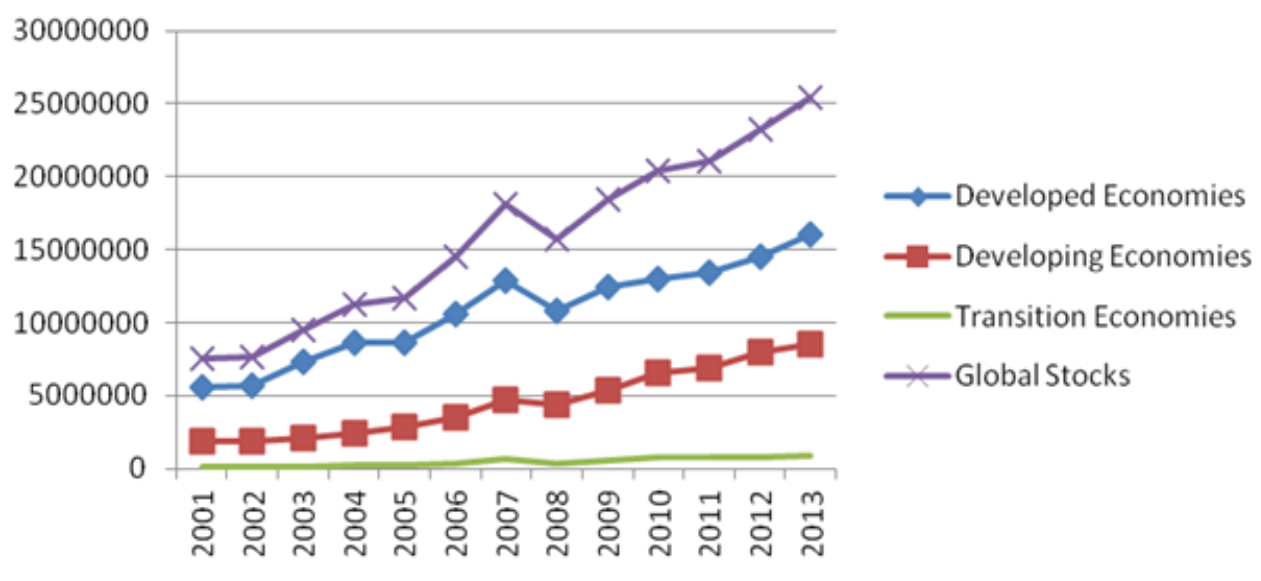

Figure 3. Global FDI stocks from 2001 to 2013 , US\$ millions

Source: UNCTAD, 2015.

\section{Anal ytical Model and Data Sources}

Several locational factors, such as macroeconomic, institutional, and social features, can attract FDI into a country or region (Dunning, 1988). Similarly, external factors (e.g. financial crises) can impact the FDI levels assigned to a particular location. To capture these effects, this study will follow a version of the partial adjustment model, which is widely used in the literature on FDI (Love \& Hidalgo, 2001; Blattner, 2006). According to this model, the current FDI stock in the country $i$ in year $t$ is explained by stock investment in the last period and several other independent variables. This resulted in the following model (Note 2): 


$$
\begin{aligned}
& F_{i, t}=\delta F D I_{i, t-1}+\beta_{0}+\beta_{1} \text { LATIN }_{i, t}+\beta_{2} \text { CRISISO }_{i, t}+\beta_{3} \text { EXTCRISIS }_{i, t}+\beta_{4} \text { CRISISOSXLATIN }_{i, t} \\
& +\beta_{5} \text { EXTCRISISXLATIN }_{i, t}+\beta_{6} \text { GDP }_{i, t}+\beta_{7} \text { OPEN }_{i, t}+\beta_{8} E_{i, t}+\beta_{9} \text { INF }_{i, t}+ \\
& \beta_{10} \text { PINVEST }_{i, t}+\beta_{11} \text { GOVSTAB }_{i, t}+\beta_{12} \text { CORRUP }_{1,} \beta_{13} \text { CRISES90 }_{i, t}+\varepsilon_{i t}
\end{aligned}
$$

The subscript $i$ shows the Latin American (Argentina, Brazil, Chile, Colombia, Costa Rica, Ecuador, Mexico, Panama, Paraguay, Peru, Uruguay, and Venezuela) or Asian (China, Hong Kong, South Korea, Singapore, Thailand, Malaysia, Indonesia, Philippines, and Vietnam) countries, and the subscript $t$ indicates the analysis period (in years) covering 1995-2014. To elect this set of explanatory variables, information contained in empirical studies (Amal \& Seabra, 2007; Montero, 2008; Liu, Chow \& Li, 2006; Hsieh \& Hong, 2004) on the attractiveness of FDI in Latin American and Asian countries is used. All variables are treated as natural logarithm (ln) to capture their elasticity. $\beta_{0}$ is the model constant.

FDI is the natural logarithm (ln) of FDI stocks in US\$ million. It was decided to use FDI stocks in the model, primarily because the partial adjustment model uses stocks. Also, FDI stocks are the result of investment flows accumulated over previous years. Additionally, the transnational corporations and a country's productive capacity are associated with investment stocks.

When following the partial adjustment model, $F D I_{i, t-1}$ is the FDI stocks lagged in one period, and, one can calculate the adjustment coefficient $\xi$ from $\delta$ (Note 3). It is believed that the lagged FDI stock has a positive and statistically significant relationship with the dependent variable, implying that the existing FDI attracts more FDI.

LATIN is a dummy variable that is included in the model to distinguish the Latin American countries (Latin = 1) from the Asian ones (Latin $=0$ ). This dummy variable aims to capture the heterogeneity between the two regions in terms of FDI attraction. A statistically significant coefficient is expected from this dummy variable, as it implies that there are differences in the FDI levels between countries in the two regions.

CRISIS08 is a dummy variable representing the international financial crisis in 2008, when there was a drop in FDI stocks worldwide, especially in Asian and Latin American countries (see Figures 2 and 3). As pointed out by Kaminsky (2006), financial crises are characterized mostly by a variety of weak economic fundamentals, indicating that it would be difficult to define them in an applied model as just a proxy or an economic variable. Thus, it was decided to express the recent financial crisis in terms of its outbreak period in the world market and of shocks on FDI stocks, defining CRISIS08 $=1$ in 2008 and CRISIS08 $=0$ in the other years.

CRISIS08XLATIN, which is the iteration between dummy variables LATIN and CRISIS08, distinguishes the effect of the financial crisis in 2008 on the Latin American countries. In this case, the iteration CRISIS08XLATIN allows testing of the null hypothesis that the effects of the financial crisis on FDI stocks are independent of the group of countries (whether Asian or Latin American). When there is iteration between dummy variables, CRISIS08 represents the average effect of the crisis on Asia countries. If the iteration CRISIS08XLATIN is statistically significant, we reject the null hypothesis, which means that the average effect of the 2008 financial crisis on Latin American countries differed from that on Asian countries. This e vidence indicates that the financial crisis has negatively impacted the FDI in both regions. However, it is expected that this negative effect is distinct, due to the heterogeneity of FDI-determining factors and the vulnerability to crisis in each region.

EXTCRISIS is a dummy variable aimed at capturing the effect of the subprime crisis extension, or the second wave of crisis contagion, on FDI levels in the countries in question. To define this variable, it is considered that the subprime crisis and its effects on FDI were not limited to 2008. EXTCRISIS takes the value 1 for all countries from 2009 to 2012 and takes the value zero for the other years. This is the period of spread of the initial crisis, especially in the developed countries, causing the public deficit crisis in the EU.

The iteration EXTCRISISXLATIN allows testing of the null hypothesis that the effects of the financial crisis extension on FDI stocks are independent of the group of countries (whether Asian or Latin American). Thus, EXTCRISIS expresses the average effect of the crisis extension on the FDI levels in Asian countries. Being statistically significant, the coefficient EXTCRISISXLATINA represents the average difference in the impact of the crisis extension on FDI levels in Latin American countries. It is believed that, in both regions, the crisis extension period was favorable to direct investment attraction due to the restructuring of these economies, implementation of counter-cyclical policies, and spread of the crisis to the developed countries.

CRISES90 is a dummy control variable used in the model to capture the shock to FDI stocks that occurred between 1997 and 2001, considering the possibility of structural breaks. This period was marked by a series of financial crises in the developing countries, the so-called crises in emerging markets (Asian Tigers Crisis in 1997; 
Russian Crisis, 1998; Brazilian Foreign Exchange Crisis, 1999; and Crisis in Argentina, 2001), and the US recession after terrorist attacks. It was stipulated that CRISES90 $=1$ for 1997-2001, a period when there were sharp fluctuations in FDI stocks in Latin American countries and, especially, in Asian countries, whereas CRISIS90 $=0$ for the remaining years.

The other variables expressed in $\beta 6$ to $\beta 12$ are also used as controls in the model and are related to possible economic and institutional FDI determinants, according to the literature (Amal \& Seabra, 2007; Montero, 2008; Liu et al., 2006; Hsieh \& Hong, 2004; Blonigen, 2005).

GDP, measured in US\$ million, is a proxy for the domestic market size. A positive relationship between GDP and FDI stocks is expected, as economic growth would attract more foreign investors interested in expanding their markets (Dunning, 2001). The degree of trade openness (OPEN) is measured through a proxy represented by the exports (FOB) plus imports (FOB) in relation to GDP in US\$ millions. This variable may have positive or negative effects on FDI. Howe ver, in empirical studies related to Asian and Latin American countries, a positive effect was predominant (Hsieg \& Hong, 2004; Amal \& Seabra, 2007). This was related to the multinationals' interest in imported capital goods and to more advanced technologies required for their production. The real effective exchange rate in US\$ (ER) is an index built by Darvas (2012) from the nominal exchange rate and a measure of the relative price between a country and its trading partners (Note 4). According to some empirical studies that use the real exchange rate in their models, it is possible to find both negative (Amal \& Seabra, 2007; Blatter, 2006) and positive effects of this variable on FDI (Barros et al, 2013; Blatter, 2006). The positive effect may be related to the real devaluation of the national currency, which would reduce the multinational's relative investment costs in the recipient country, compared to the country of origin. However, this same devaluation could increase the value of imports that are very important for the productive structure of multinationals. The inflation rate of countries (INF) represented by the GDP deflator, based on the Consumer Price Index (CPI), is a proxy for economic stability. By generating uncertainty and undermining the real income of consumers, the increase in the inflation rate could contain foreign investors. Therefore, a negative effect of the inflation rate on FDI levels is expected.

The corruption control (CORRUP) is an index built by the Political Risk Service (PRS) to assess corruption within the political system (Note 5). The index ranges from 0 to 6 points - the higher the index, the greater the control exercised over corruption. Increased control over corruption can improve the economic, political, and social environment of a country, thereby attracting more FDI. The investment profile (PINVEST) is a PRS index consisting of the sum of three subcomponents: a feasibility/expropriation contract, profit repatriation, and late payments. Each of these components has a score of 0 to 4, and the general index is the sum of the three components (index $=12$, implies low risk for investments). In general, the higher the index, the lower the risk for foreign capital and the better the situation for FDI (positive relationship). Governmental stability (GOVSTAB) is a proxy for political risk, linked to the government's ability both to carry out its planned programs and to stay in office, which is also built by PRS, based on the sum of three other categories: government unity, legislative force, and popular support. The general index ranges from 0 to 12, with 12 being the most stable government (lower political risk). For the foreign investor, a country where the government has the stability to conduct the appropriate policies for economic development is a better prospect.

The stock of FDI in US\$ millions is an annual series available on the website of the United Nations Conference on Trade and De velopment (UNCTAD) and the real GDP (at 2005 constant prices). The series for exports (FOB) and imports (FOB) are also expressed in US\$ million and are found on the World Bank website (World Development Indicators), in addition to the inflation rate measured by the GDP deflator. The real exchange rate is an index built by Darvas (2012). The investment profile, control of corruption, and government stability are indices constructed by the PRS through the International Country Risk Guide and must be purchased through the website. All these data series are complete, both for the period in question and for all countries involved. In the case of FDI stock, data were deflated with the US Consumer Price Index, available on the US Inflation Calculator, taking 2005 as the base year.

\section{Results and Discussions}

In this study, the model estimates are performed by using the system GMM estimator (Generalized Method of Moments), based on the works by Arellano and Bover (1995) and Blundell and Bond (1998). The choice of this estimator is justified by the need to address the following issues: a lagged dependent variable $\left(F D I_{i, t-1}\right)$ used as a regressor, which features a dynamic panel; the presence of explanatory variables not strictly exogenous; unobserved heterogeneity, and time-invariant factors among the sample countries; and possible autocorrelation in the individual units and heteroscedasticity across the countries. 
The model expressed above, in (1), was estimated. This estimation considered the robust standard error option, the possibility of heteroscedasticity, and treatment of the variable GDP as being endogenous to the model and the variables OPEN and ER as being predetermined. Moreover, lagged values were used as instruments corresponding to the momentum conditions, both in level and first difference, considering the explanatory and dependent variables (Note 6). The results are presented in Table 1.

Table 1. Dynamic Panel Results

\begin{tabular}{llc}
\hline & \multicolumn{1}{c}{ Depended Variable: FDI } & \\
\hline FDI $(-1)$ & \multicolumn{1}{c}{ Coefficients } & Robust standard error \\
GDP & $0.8341 * * *$ & 0.03349 \\
OPEN & $0.2469 * * *$ & 0.05440 \\
ER & $0.2107 * * *$ & 0.05616 \\
INF & $0.2600 * * *$ & 0.07731 \\
PINVEST & 0.1306 & 0.01509 \\
STBGOV & $0.2247 *$ & 0.09136 \\
CORRUP & -0.0128 & 0.07643 \\
LATIN & 0.0505 & 0.03314 \\
CRISES90 & $0.3096^{* * *}$ & 0.08813 \\
CRISIS08 & $-0.0976^{* * *}$ & 0.01934 \\
EXTCRISIS & $-0.1757^{* * *}$ & 0.06645 \\
CRISISO8XLATIN & $0.04887 * * *$ & 0.01949 \\
EXTCRISISXLATIN & $0.1565 * *$ & 0.07452 \\
CONSTANT & -0.0149 & 0.02623 \\
\hline
\end{tabular}

Number of observations $=345$

Number of groups $=21$

Number of instruments $=275$

Instruments for differentiated equation:

GMM = IDE(-2), OPEN(-1), CAM(-1), PIB(-2)

Instruments for level equation:

GMM = D.IDE(-1), D.OPEN, D.CAM, D.PIB(-1)

Note: $* * * 1 \%$ significance, $* * 5 \%$ significance $* 10 \%$ significance.

Source: results.

Overall, the results indicated the model adequacy, with a strong relationship between FDI stocks and most of the items proposed in the literature. The importance of lagged FDI as an explanatory variable for the current stock investment is especially remarkable. Its coefficient, $\delta=0.83$, was positive and highly significant. While this coefficient shows the short-term impact on current FDI stocks, the balanced adjustment rate is given by $\xi=1-$ $\delta$, which results in $\xi=0.17$. This rate implies that the adjustment to the desired FDI stock is neither complete nor instantaneous and that only $17 \%$ of the short-term and long-term differences are adjusted each period (year). This is due to the rigidity of the production process, inertia, and existing contractual obligations, which hinder the adequacy of the existing inventory vis-à-vis the desired capital stock.

With regard to the economic explanatory variables, the model showed that, from 1995 to 2013, factors such as market size (GDP), OPEN, and ER had a statistically significant positive relationship with FDI stock, thereby being important determinants of this investment level in the sample countries. Inflation rate has a positive sign, but it was not statistically significant in the model. Among the explanatory variables that represent institutional environment, PINVEST was important for FDI attraction, as it has a positive significant relationship with the FDI. The variables representing government stability and corruption control were not statistically significant in the model. The dummy variable that represents the crisis period in the 1990s in the developing countries, CRISES90, had a highly significant negative coefficient. These crises undermine the foreign investment attraction to countries in the regions investigated. The dummy variable LATIN had a positive sign and was statistically significant, only indicating that the FDI level between two regions is different.

The dummy variable CRISIS08 was negative and statistically significant, indicating that the financial crisis in 2008 had a negative impact on the FDI stock in Asian countries. When keeping everything constant during the crisis, FDI stocks in Asian countries fell by $17.57 \%$, on average, compared to other periods. Importantly, this negative effect of the crisis on FDI cannot be associated with any fluctuation in the variables expressed in the model (e.g., drop in GDP), since such variables are constants.

Besides the risks and uncertainties arising from the crisis, and the difficulty of capturing credit, other factors can help explain this FDI drop in Asian countries. A sharp decline in demand from developed countries caused a decrease in the Asian countries' exports, thus affecting the export-oriented FDI in the region. The crisis also 
affected the financial sector in many countries in the region, especially Hong Kong and Singapore, which are traditional international financial centers. Malaysia, for instance, with a much more internationalized financial market, was quickly contaminated by the crisis, which compromised the country's credit structure and capital markets.

The interaction CRISIS08XLATIN was statistically significant at 5\%, confirming that the effect of the crisis on FDI stocks differs between Asian and Latin American countries. The coefficient value indicates the deviation around the mean. Thus, the impact of the crisis on FDI stocks in Latin America was $-0.0192(-0.1757+0.1565)$. This indicates that, by keeping everything constant, FDI stocks in Latin America fell by $2 \%$, on average, during the crisis, compared to other periods. It was expected that this crisis had a negative impact on FDI, associated with both the risks and uncertainties of the period and the deterioration of other economic and financial factors that determine the FDI.

According to ECLAC (2009), several factors may be related to this FDI drop in Latin American countries. These factors include a drop in commodity prices in late 2008, which affected investments in natural resources; and the US recession, which has damaged investment in export platforms in Mexico and Central America. Moreover, the crisis also hit production and investments in European countries, which are among the main investors in Latin America.

The analysis of the dummy variable CRISIS08 and its interaction CRISIS08XLATIN shows that the subprime crisis had a negative impact on the countries of the two regions. These dummy variables also show that the impact of the crisis differed between the regions, as the FDI stock retreated more in Asian than in Latin American countries. It is believed that these differences are related to the vulnerability and heterogeneity of the countries in each region: both these factors are FDI determinants not included in the model. The dummy variable EXTCRISIS was statistically significant at 5\% and presented a positive sign, showing that the FDI stock increased by 5\%, on average, in Asian countries during the spread of the crisis from 2009 to 2012. The interaction EXTCRISISXLATIN had a positive coefficient, but it was not statistically significant. This implies that there is no evidence the post-crisis period has had differentiated impact among the countries in Asia and Latin America.

By following this interpretation, it is expected that the FDI stocks have also increased by 5\% in Latin America during the spread of the crisis. This result meets expectations and may be linked to several factors, such as counter-cyclical policies adopted by local governments in both regions to revive economies and specific policies for attracting foreign capital. It should also be considered, among other factors mentioned, that uncertainties and risks in developed economies made foreign investors redirect their capital to countries that are less affected by the turbulence and/or have better prospects for economic performance. With the developed countries still undergoing the crisis effects in 2011, Latin American countries, like Brazil, Chile, and Colombia, increased their credibility in the region and encouraged market-seeking investments-linked to both demand attractiveness and middle class growth of these countries (Birdsall, 2012). In Asia, regional trade was growing again, especially between China and the ASEAN (Association of Southeast Asian Nations) countries, with the discussion of an agreement for a free trade area, which strengthened regional integration and inter-regional FDI (UNCTAD, 2010).

The moment conditions used in GMM system estimation would be valid only if the errors are not auto-correlated. The Arellano-Bond autocorrelation test is applied to the equation errors in first difference, considering the firstand second-order autocorrelations. Then, the null hypothesis is tested for no serial correlation in second order. Normally, the null hypothesis is rejected in the first-order autocorrelation, without being a problem of poor model specification. In the case of the second-order correlation, it is expected that the null hypothesis will be not rejected, signaling the validity of the moment conditions used.

In this case, the Arellano-Bond test for error autocorrelation indicates that errors are correlated in the first order. However, as seen in Table 2, there is no evidence of serial correlation in the second-order differentiated errors (i.e. H0 not rejected). This implies that the moment conditions used in the GMM system are valid and, thus, validate the model results.

Table 2. Arellano-Bond test for error autocorrelation

\begin{tabular}{ccc}
\hline Order & $\mathrm{z}$ & Prob $>\mathrm{z}$ \\
\hline 1 & -2.96 & 0.0030 \\
2 & -0.87 & 0.3999 \\
\hline
\end{tabular}

Note: H0: no correlation.

Source: results. 


\section{Conclusions}

This study evaluates the impact of the international financial crisis (subprime) on FDI behavior in Asian and Latin American emerging countries. Through the econometric model, it was found that the 2008 financial crisis had a negative impact on FDI levels in both regions studied. However, the magnitude of the crisis effect was different in the two regions, reducing more FDI stocks in Asia than in Latin America. It is believed that this difference is mainly associated with the vulnerability and heterogeneity of the countries' macroeconomic and institutional structures. In addition, these developing Asian and Latin American countries were not adversely affected by the crisis spread, in terms of FDI stock, compared to the developed countries. On the contrary, during this period, the developing countries attracted more foreign investments. It is believed that this reflects the counter-cyclical policies adopted by these countries to attract FDI. Also, it may reflect the uncertainties and risks related to the developed economies.

Additionally, the econometric model results showed the importance, not only of lagged FDI but also of economic and institutional variables (e.g. GDP, exchange rate, trade liberalization degree and investment profile), for attraction of direct investments during the period of study in Asian and Latin American countries .

The international financial crisis and its extension have caused serious consequences in various aspects of the world economy (e.g. financial breaks, and falls in production, trade, employment etc.), and this article revealed effects on FDI in the emerging countries studied. For many developing countries, where FDI compensates for lack of domestic private investment, it is important to understand that this results in a better understanding of FDI behavior. It would be particularly important for the local governments to consider the formulation of public policies in terms of capital attraction and for protection during financial crises that undermine the whole economic structure. Thus, there should be measures to strengthen financial systems (e.g. stricter regulations, constant supervision, and consultation with international financial institutions) and macroeconomic measures to prevent crises through more balanced monetary and fiscal policies, without compromising the public accounts and the financial system. However, in the face of crises, there are critical policies, such as the policies for tax and credit access that reheat domestic demand and attract more foreign investment.

In addition, by studying the relationship between crisis and FDI in Asian and Latin American emerging countries, we can contribute to the characterization of the current investment behavior in the developing countries at a global level. For future studies, we intend to extend this analysis to developed countries, both to allow a more general understanding of the subject and to facilitate comparison of the results with the developing countries.

\section{References}

Alfaro, L., \& Chen, M. (2010). Survi ving the global financial crisis: foreign direct investment and establishment performance. Harvard Business School, working paper, 10-110. https://doi.org/10.2139/ssm.1623831

Allen, F., \& Carletti, E. (2009). .An overview of the crises: causes, consequences and solutions. Paper presented at the conference on Global Market Integration and Financial Crises, Hong Kong Uni versity of Science and Technology, Hong Kong. Retrieved from http://apps.eui.eu/Personal/Carletti/IRF-Overview-Allen-Carletti-26Nov09-final.pdf

Amal, M., \& Seabra, F. (2007). Determinantes do investimento direto externo (IDE) na América Latina: uma perspective institucional. Revista Economia, 8(2), 231-247.

Arellano, M., \& Bond, S. (1991). Some tests of specification in panel data: Monte Carlo evidence and an application to employment equations. Review of Economic Studies, 58(2), 277-297. https://doi.org/10.2307/2297968

Arellano, M., \& Bover, O. (1995). Another look at the instrumental variables estimation of error components models. Journal of Econometrics, 68(1), 29-51. https://doi.org/10.1016/0304-4076(94)01642-D

Athukorala, P. (2003). Foreign direct investment in crisis and recovery: lessons from the 1997-1998 Asian crises. Australian Economic History Review, 43(2), 197-213. https://doi.org/10.1111/1467-8446.t01-1-00051

Barros, C., Chen, Z., \& Damasio, B. (2013). Attracting foreign direct investment: an analysis of Asian countries. Centro de Estudos sobre África e Desenvolvimento, working paper, 116. Retrieved from http://pascal.iseg.utl.pt/ cesa/index.php/menupublicacoes

Birdsall, N. (2012). A note on the middle class in Latin America. Center for Global Development, working paper, 303. Retrieved from

http://www.cgdev.org/publication/note-middle-class-latin-america-working-paper-303 pdf

Blattner, T. (2006). What drives foreign direct investment in Southeast Asia? A dynamic panel approach. 
European Central Bank. Retrieved from

http://faculty.washington.edu/karyiu/confer/seoul06/papers/blattner.pdf

Blomström, M., \& Persson, H. (1983). Foreign investment and spillover efficiency in an underdeveloped economy: evidence from the Mexican manufacturing industry. World Development, 11(6), 493-501. https://doi.org/10.1016/0305-750X(83)90016-5

Blonigen, B. (2005). Areview of the empirical literature on FDI determinants. Atlantic Economic Journal, 33(4), 383-403. https://doi.org/10.1007/s11293-005-2868-9

Blundell, R., \& Bond, S. (1998). Initial conditions and moment restrictions in dynamic panel data models. Journal of Econometrics, 87, 115-143. https://doi.org/10.1016/S0304-4076(98)00009-8

Borensztein, E., De Gregorio, J., \& Lee, J. (1998). How does FDI affect economic growth? Journal of International Economics, 45(1), 115-135. https://doi.org/10.1016/S0022-1996(97)00033-0

Campello, M., Graham, J., \& Harvey, C.(2010). The real effects of financial constraints: evidence from a financial crisis. Journal of Financial Economics, 97(3), 470-487. https://doi.org/10.1016/j.jfineco.2010.02.009

Claessens, S., \& Kose, M. (2013). Financial crises: explanations, types, and implications. International Monetary Fund, IMF Working Paper, 13/28. https://doi.org/10.5089/9781475561005.001

Darvas, Z. (2012). Real effective exchange rates for 178 countries: a new database. Bruegel Working Paper 2012/06. Retrieved from http://bruegel.org/2012/03/real-effective-exchange-rates-for-178-countries-a-new-database/

Dunning, J. (1988). Trade, location of economic activity and the multinational enterprise: a search for an eclectic approach. In: Dunning, J. (ed.). Explaining international production, 13-40. London: Unwin Hyman.

Dunning, J. (1992). Multinational enterprises and the global economy. Wokingham, England: Addison-Wesley.

Dunning, J. (2001). The eclectic (OLI) paradigm of international production: past, present and future. International Journal of the Economics of Business, 8(2), 173-190. https://doi.org/10.1080/13571510110051441

Economic Comission for Latin America and Caribbean - ECLAC. (2009). La inversión directa extranjera en América Latina y el Caribe: ECLAC, 2009. Retrieved from

https://www.cepal.org/es/publicaciones/1140-la-inversion-extranjera-directa-america-latina-caribe-2009

Goldsmith, R. (1982). Comment on Hyman P. Minsky's financial instability hypothesis: capitalist processes and the behavior of the economy. In: Kindleberger, C. P. and Laffargue, J. P. (eds.). Financial crises: theory, history and policy. Cambridge: Cambridge University Press.

Graham, E., \& Wada, E. (2000). Domestic reform, trend and investment, financial crisis and foreign direct investment in Mexico. The World Economy, 26(6), 777-797. https://doi.org/10.1111/1467-9701.00303

Herman, M., Chisholm, D., \& Leavell, H. (2004). FDI and the effects on society. Proceedings of the Academy for Studies in International Business, 15-18. New Orleans.

Hsieh, W., \& Hong, M. C. (2004). The determinants of foreign direct investment in Southeast Asian transition economies. Proceedings of the International Symposium on Foreign Trade - FDI and industrial development, 131-144. Chia-Yi, Taiwan: National Chung Cheng University.

Joyce, J., \& Nabar, M. (2009). Sudden stops, banking crises and investment collapses in emerging markets. Journal of Development Economics, 90(2), 314-322. https://doi.org/10.1016/j.jdeveco.2008.04.004

Kaminsky, G. (2006). Currency crises: are they al the same? Journal of International Money and Finance, 25(3), 503-527. https://doi.org/10.1016/j.jimonfin.2006.01.002

Kindleberger, C., \& Aliber, R. (2005). Manias, panics and crashes: a history of financial crises (5th ed.). New Jersey: John Wiley \& Sons Inc. https://doi.org/10.1057/9780230628045

Krugman, P. (2000). Fire-sale FDI. In: Edwards, S. (ed.). Capital flows and the emerging economies: theory, evidence, and controversies, (pp. 43-58). Chicago: University of Chicago Press.

Lipsey, R. (2001). Foreign direct investors in three financial crises. National Bureau of Economic Research, Working Paper, 8084. https://doi.org/10.3386/w8084

Liu, L. G., Chow, K., \& Li, U. (2006). Determinants of foreign direct investment in East Asia: did China crowd 
out FDI from her developing East Asian neighbors? Hong-Kong Monetary Authority: Economic Research Division. Retrieved from http://www.hkma.gov.hk

Loungani, P., \& Razin, A. (2001). How beneficial is foreign direct investment for developing countries? Finance and Development, 38(2), 6-9.

Love, J., \& Hidalgo, F. (2001). Analyzing the determinants of US direct investment in Mexico. Applied Economics, 32(10), 1259-1267. https://doi.org/10.1080/000368400404416

Mello, P., \& Spolador, H. (2010). Crises financeiras: quebras, medos e especulações do mercado (1st ed.). São Paulo: Saint Paul.

Minsky, H. (1986). Stabilizing an unstable economy. New Haven: Yale University Press.

Mongelli, F. (2013). The mutating Euro area crisis: is the balance between the "sceptics" and "advocates" shifting? European Central Bank. Retrieved from https://papers.ssrn.com/sol3/papers.cfm?abstract_id=2217605

Montero, A. (2008). Macroeconomic deeds, not reform words: the determinants of foreign direct investment in Latin America. Latin American Research Review, 43(1), 55-83. https://doi.org/10.1353/lar.2008.0008

Organisation for Economic Co-operation and Development - OECD. (2008). OECD benchmark definition of foreign direct investment, (4th $\quad$ ed.). Retrieved from http://www.oecd.org/daf/inv/investmentstatisticsandanalysis/40193734.pdf

Penfold, M. (2014). Institutions and foreign direct investment in Latin America: a new emerging reality. LAC working papers in political economy, Working Paper 3. Retrieved from http://www.lac.ox.ac.uk/sites/sias/files/documents/LAC\%20Working\%20Paper\%20in\%20Political\%20Econ omy\%20No\%203\%2C\%20Michael\%20Penfold\%2C\%20July\%202014.pdf

Political Risk Service - PRS. (2014). International Country Risk Guide (ICRG) 2014. Retrieved from http://www.prsgroup.com/icrg.aspx

Poulsen, L., \& Hufbauer, C. (2011). Foreign direct investment in times of crisis. Transnational Corporations, 20(1), 19-38. https://doi.org/10.18356/138883a0-en

Ramamurti, R. (2011). Impact of the crisis on new FDI players: past, present and future of sovereign wealth funds, private equity and emerging market transnational corporations. Transnational Corporations, 20(1), 39-68. https://doi.org/10.18356/7fbcef8d-en

Reinhart, C., \& Rogoff, K. (2009). This time is different: eight centuries of financial folly. Princeton: Princeton University Press.

Taylor, A. (2012). The great leveraging. Paper presented at 11th BIS Annual Conference: The future of financial globalisation. Lucerne, Switzerland. https://doi.org/10.3386/w18290

Ucal, M., Özcan, K., Bilgin, M., \& Mungo, J. (2010). Relationship between financial crisis and foreign direct investment in developing countries using semiparametric regression approach. Journal of Business Economics and Management, 11(1), 22-33. https://doi.org/10.3846/jbem.2010.02

United Nations Conference on Trade and Development - UNCTAD. (2005). World investment report 2005 : transnational corporations and internationalization of $R \& D$. Retrieved from unctad.org/en/Docs/wir2005_en.pdf

United Nations Conference on Trade and Development - UNCTAD. (2010). World investment report 2010: investing in a low-carbon economy. Retrieved from unctad.org/en/Docs/wir2010_en.pdf

United Nations Conference on Trade and Development - UNCTAD. (2015). UNCTAD Statistics. Retrieved from http://unctadstat.unctad.org/ReportFolders/reportFolders.aspx

US inflation calculator, (2015). Consumer Price Index, 2015. Retrieved from http://www.usinflationcalculator.com

World Bank Data. (2015). World Development Indicators, 2015. Retrivied from http://data.worldbank.org/data-catalog/world-development-indicators 


\section{Notes}

Note 1. According to Dunning (1992) there are some motivations and determinants that lead firms to compete in the international market. These motivations are mainly linked to economic structure and governmental policies and can be divided into four basic groups: resource seeking, market seeking, efficiency seeking, and strategic asset seeking. Specifically, in strategic asset seeking the acquisition of resources and strategic assets is the main objective for companies seeking to strengthen their competitive position and increase their skills in regional and global markets.

Note 2. The model expressed in (1) is a general model including all the sample countries, both Asian and Latin American. It would be possible to estimate a model for each group of countries separately. However, in different models it is not possible to compare the magnitude of the estimated coefficients in each region; it is only possible to compare the revealed signs.

Note 3. The investment variation in period $t$ is a fraction $\xi$ of the desired range for that period. When $\xi=1$, the effective capital stock would be equal to the desired stock (instant adjustment). When $\xi=0$ there would be no investment in $t$ (effective capital in $t$ would be equal to the capital from the previous period). Overall, what happens is that $0<\xi<1$ and the adjustment to the desired capital stock tends to be incomplete due to rigidity, inertia, and contractual obligations.

Note 4 . The index is a weighted geometric mean of bilateral exchange rate indices, where the weights reflect the relative importance of each partner in trade. The price measure used is the Consumer Price Index (CPI) of the country, taking into account 67 trading partners by country (Darvas, 2012).

Note 5. In order to construct this index, special consideration is given to the kind of potential corruption linked to nepotism, paternalism, favor exchange, illegal financing of parties, and misappropriation of funds and public money. Also, corruption is considered to be linked to financial issues, in the form of special payments, loans, tax incentives, and licenses (PRS, 2015).

Note 6 . The system is constructed with (T-2) equations in difference and (T-2) level equations, corresponding to periods $3, \ldots \mathrm{T}$, for possible instruments.

\section{Copyrights}

Copyright for this article is retained by the author(s), with first publication rights granted to the journal.

This is an open-access article distributed under the terms and conditions of the Creative Commons Attribution license (http://creativecommons.org/licenses/by/4.0/). 